\title{
Applications of CRISPR/Cas9 in the research of malignant musculoskeletal tumors
}

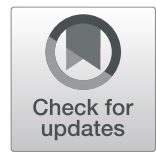

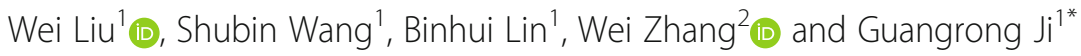

\begin{abstract}
Background: Malignant tumors of the musculoskeletal system, especially osteosarcoma, Ewing sarcoma and rhabdomyosarcoma, pose a major threat to the lives and health of adolescents and children. Current treatments for musculoskeletal tumors mainly include surgery, chemotherapy, and radiotherapy. The problems of chemotherapy resistance, poor long-term outcome of radiotherapy, and the inherent toxicity and side effects of chemical drugs make it extremely urgent to seek new treatment strategies.

Main text: As a potent gene editing tool, the rapid development of CRISPR/Cas9 technology in recent years has prompted scientists to apply it to the study of musculoskeletal tumors. This review summarizes the application of CRISPR/Cas9 technology for the treatment of malignant musculoskeletal tumors, focusing on its essential role in the field of basic research.

Conclusion: CRISPR, has demonstrated strong efficacy in targeting tumor-related genes, and its future application in the clinical treatment of musculoskeletal tumors is promising.
\end{abstract}

Keywords: CRISPR/Cas9, Gene editing, Osteosarcoma, Ewing's sarcoma, Rhabdomyosarcoma

\section{Background}

Clustered regularly spaced short palindromic repeats, i.e.,The CRISPR sequence was initially identified in $E$. coli [1]. and was later confirmed to be widespread in bacteria and archaea. The sequence consists of nonadjacent identical sequences (repeats) and variable sequences (spacers) that are similar in size. The CRISPR sequence is adjacent to the CRISPR related gene (CAS9) and together constitutes the CRISPR/CAS9 system, CRISPR, is an important component of the immune defence system of prokaryotes, providing them with adaptive immunity against phage infection and plasmid transfer [2-4]. The CRISPR sequence can produce mature CRISPR RNA (crRNA) after transcriptional and enzymatic processing [5]. The repeated sequence of crRNA with CAS nuclease

\footnotetext{
*Correspondence: Liu18020757865@163.com

'Department of Orthopaedics, Xiang'an Hospital, School of Medicine, Xiamen University, No. 2000 East Xiang'an Road, Xiang'an District, Xiamen 361102, China

Full list of author information is available at the end of the article
}

pairs with trans-activated crRNA (tracrRNA) bases to form a complex with a double-RNA hybrid structure. The crRNA spacer can be integrated with the exogenous phage genome spacer (prospacer) to enable the bacteria to form an immune memory of the exogenous gene, thereby increasing the host's phage resistance [6]. CAS9 can then be directed to specific target DNA loci for cleavage to produce a blunt-ended double-strand breaks (DSBs) [7], In mammalian cells, DSBs are then repaired by either homology-directed repair (HDR) [8] or nonhomologous end joining (NHEJ) [9]. Due to its high fidelity, HDR can perform precise genetic repair, whereas NHEJ performs error-prone and inaccurate repairs by generating random deletions or insertions at the break site.

Beyond an important role in prokaryotes, CRISPR/ CAS9 gene editing technology was applied for mammalian cell genome editing by Mali [10] and Cong [11]. et al. for the first time in 2013, by modifying the bacterial CRISPR system to allow mammalian cells to heterologously express key components of the prokaryote CRIS

(c) The Author(s). 2021 Open Access This article is licensed under a Creative Commons Attribution 4.0 International License, which permits use, sharing, adaptation, distribution and reproduction in any medium or format, as long as you give appropriate credit to the original author(s) and the source, provide a link to the Creative Commons licence, and indicate if changes were made. The images or other third party material in this article are included in the article's Creative Commons licence, unless indicated otherwise in a credit line to the material. If material is not included in the article's Creative Commons licence and your intended use is not permitted by statutory regulation or exceeds the permitted use, you will need to obtain permission directly from the copyright holder. To view a copy of this licence, visit http://creativecommons.org/licenses/by/4.0/. The Creative Commons Public Domain Dedication waiver (http://creativecommons.org/publicdomain/zero/1.0/) applies to the data made available in this article, unless otherwise stated in a credit line to the data. 
PR system or an artificially designed crRNA-tracrRNA fusion transcript (gRNA), which can direct CAS9 to the target DNA sequence and perform targeted cleavage to achieve gene knockout. The basic working mechanism of CRISPR/CAS9 in mammalian cells is shown in Fig. 1. Since then, CRISPR/CAS9 technology has quickly become a research hotspot in the basic sciences and biomedical fields. Generally, CRISPR/CAS9 technology is superior to ZFN and TALEN gene editing techniques widely used in the past based on the following aspects: 1 . The design is simpler. With the same CAS9 nuclease, the new DNA target sequence can be edited again only by replacing the sgRNA sequence, which saves time [12, 13]. 2. Higher gene editing efficiency. sgRNAs are relatively short and multiple sgRNAs can be introduced to achieve simultaneous editing of multiple target genes [14]. 3. Higher targeted binding efficiency and lower cost [13]. These unique advantages of CRISPR/CAS9 technology have promoted its use in research in the field of biomedicine and have made major breakthroughs in the clinical treatment of human diseases. For example, scientists engrafted CCR5-knockout HSPCs by CRISPR/ CAS9 technology into patients with both acute lymphocytic leukemia (ALL) and HIV infection. Complete remission of ALL was achieved without adverse events related to gene editing, and the percentage of $\mathrm{CD} 4+$ cells ablated by CCR 5 in this patient was increased after discontinuing antiretroviral treatment [15]. In addition, CRISPR/Cas9 technology has now been widely applied in various clinical trials for treating human diseases such as blood diseases, hereditary eye diseases, viral diseases and cancers, including malignant glioma, metastatic non-small cell lung cancer, prostate cancer, oesophageal cancer, and renal cell cancer [16]..

Malignant musculoskeletal tumors most commonly occur in adolescents and children, and osteosarcoma, Ewing's sarcoma (ES) and rhabdomyosarcoma exhibit the highest incidences. The current main treatment methods include surgery, chemotherapy and radiation therapy [17]. The application of combination therapy has improved the prognosis of patients compared with previous single surgical resection, but the toxicity and side effects of chemotherapy drugs, the risk of long-term tumor recurrence and new cancers induced by radiotherapy, mean that new treatments with low toxicity side effects and better long-term efficacy are urgently needed. The benefits of CRISPR/CAS9 technology in basic research and clinical applications in various human diseases have promoted its exploration in musculoskeletal tumors, including screening and knockout of oncogenes or drug-resistant genes, identification of tumor suppressor genes and construction of cell or animal tumor models. An in-depth understanding of the application status and application challenges of CRISPR/CAS9 technology in the study of malignant musculoskeletal tumors will help accelerate the research progress of these tumors. In this review we describe the recent exciting progress in the use of CRISPR/Cas9 technology in the race to develop treatments for malignant musculoskeletal tumors.

\section{Osteosarcoma and CRISPR/CAS9}

Among skeletal tumors in adolescents and children, osteosarcoma has the highest incidence, ranking third among all childhood tumors, second only to lymphoma and brain cancer, and accounting for approximately $1 \%$ of adult tumors $[18,19]$. Only 800 new cases are reported annually in the U. S, and the prognosis for patients with osteosarcoma is often unsatisfactory despite the relatively low incidence [18]. The overall ten-year survival rate is only approximately $50 \%[20,21]$. It is worth noting that 30 to $40 \%$ of patients with local tumors will relapse after treatment [19], greater than $80 \%$ of the local tumor may metastasize, and approximately

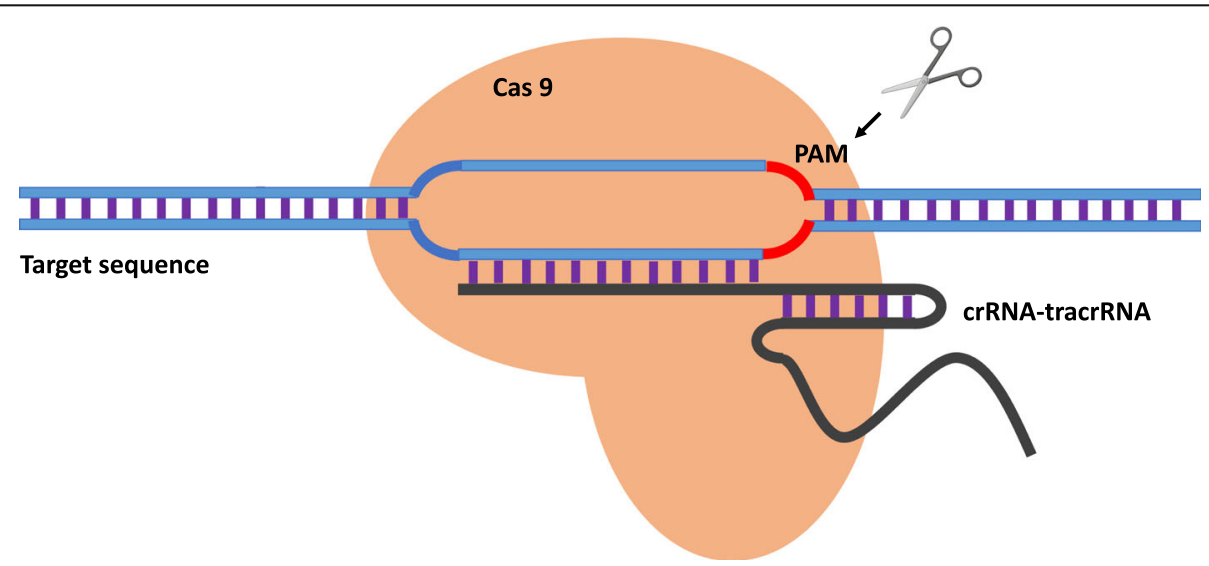

Fig. 1 The basic working mechanism of CRISPR/CAS9 in mammalian cells. The crRNA-tracrRNA fusion transcript (gRNA) combines with the CAS9 protein to form a complex that targets the DNA sequence and knocks out target genes 
$20 \%$ of tumors had metastasized when the disease is diagnosed [18]. For those with metastasis or relapse, less than $30 \%$ survived in the next five years [19]. The current treatment plan is mainly neoadjuvant chemotherapy plus surgery combined with postoperative chemotherapy for at least 6 to 8 months. The preferred chemotherapy regimen is a MAP combination regimen consisting of cisplatin, high-dose methotrexate, and Adriamycin [18, 21, 22]. The use of combined chemotherapy has improved patient survival to some extent, but the toxic side effects of chemotherapy drugs have aroused people's concerns, such as the cardiotoxicity of doxorubicin [23], the otorenal toxicity and carcinogenicity of cisplatin [24-26], methotrexate-induced bone marrow suppression and liver, kidney, and ocular mucosal toxicity $[25,26]$.. Another concern is the resistance of tumors to chemotherapy, which often causes disease recurrence and reduces patient survival [27]. To overcome these clinical problems, we need to understand the pathogenesis of osteosarcoma and control it at the genetic level. Although the exact aetiology of osteosarcoma is unknown, there is evidence that hereditary diseases such as hereditary retinoblastoma, Li-Fraumeni syndrome, Rothmund-Thomson syndrome and Werner syndrome may affect the occurrence of osteosarcoma, and the disease-causing genes of these syndromes are $R B 1$, TP53, RECQL4 and WRN, suggesting that abnormalities in these genes may form part of the pathogenesis of osteosarcoma $[18,28]$. In addition, germline genes and pharmacogenetics also profoundly affect the treatment of osteosarcoma, including genes related to drug transport and DNA repair, such as $A B C C 3, A B C B 1, R F C 1$, GST family, ERCC1, ERCC2 and XPC. ABCC3, $A B C B 1$, $R F C 1$, and GST are genes encoding drug transporters, whereas ERCC1, ERCC2, and XPC are involved in the repair of DNA damage induced by cisplatin. Many studies have demonstrated that mutations in these genes affect drug sensitivity in patients with osteosarcoma and are often associated with poor prognosis [29-36]. Because CRISPR/CAS9 can precisely target pathogenic genes, its application in the treatment of osteosarcoma is promising. In recent years, some progress has been made in CRISPR/CAS9 technology in the area of osteosarcoma (summarized in Table 1), and its major applications are presented in Fig. 2.

Feng. et al. first applied CRISPR/CAS9 technology to osteosarcoma research in 2014 when they knocked out the CD11K genes of KHOS and U-2OS human osteosarcoma cells, and demonstrated significant inhibition of migration, invasion activity and cell proliferation [37]. Since then, the CRISPR/CAS9 technique has been widely applied for osteosarcoma oncogene knockout. A study showed that human Saos osteosarcoma cells were nonviable when the GLT25D1 and GLT25D2 genes were knocked-out [38]. CD44 knockout suppressed the mobility of 143B and MNNG/HOS cells, both of which are highly invasive human osteosarcoma cell lines, and their spheroid formation and growth were also significantly inhibited [39]. In addition, CRISPR/CAS9 gene-edited cells also exhibited similar effects in vivo. In one study, CD81 knock-out 143B cells were injected into nude mice, and the occurrence of pulmonary metastases was significantly reduced compared with the control group [40]. Another study used MG63 and U2OS cells in which the FGF5 gene was knocked out to perform tibia in situ transplantation in nude mice, and tumor growth in vivo was significantly inhibited [41]. It is worth noting that CRISPR/CAS9 technology can be applied to improve the chemosensitivity of osteosarcoma cells. KHOSR2, a multidrug-resistant osteosarcoma strain, exhibited increased sentivity to Adriamycin by mutant TP53 knockout [42]. PD-L1-knockout made KHOS and MNNG/HOS cells more sensitive to paclitaxel and doxorubicin [43]. For KHOSR2 and U-2OSR2, the expression of the drug efflux protein p-gp encoded by $A B C B 1$ was significantly reduced with increased doxorubicin absorption and sensitivity after CD44-knockout by CRISPR/CAS9 technology [44]. When direct knockout of the $A B C B 1$ gene was performed in KHOSR2 and $\mathrm{U}-2 \mathrm{OS}$ cells, the chemoresistance of these cells to Adriamycin was effectively reversed [45]. These experiments suggest that targeted oncogene knockout via CRISPR/ CAS9 technology has the potential to inhibit osteosarcoma progression, and hopefully overcome the problem of chemoresistance.

In addition to knocking out oncogenes, CRISPR/CAS9 technology was also used to edit cancer suppressor genes to verify their biological roles. The CRISPR/CAS9mediated knockout of CNE9, CNE10 or STAG2 gene could decrease U2OS cell apoptosis. CNE9 or CNE10 knock-out U2OS cells exhibited significantly inhibited cell proliferation, suggesting the cancer suppressor roles of both genes, For STAG2-knockout cells, the epithelialmesenchymal transition (EMT), cell invasion and PD-L1 gene expression were obviously promoted, whereas expression changes of many immune-related genes and increased chemo-resistance to cisplatin were also observed, indicating that the absence of STAG2 may protect tumor cells from attack by the immune system mediated by PD-L1, which may offer evidence that STAG2 is possibly a new potential biomarker for $P D-1$ PD-L1 inhibitor therapy in STAG2-deficient osteosarcoma $[46,47]$. Decitabine (DAC), a DNA methylation inhibitor can inhibit in vitro cell proliferation, mobility, anchoring independence, and spheroid formation, reduce in vivo xenograft tumor growth and metastasis and reduce the expression of tumor stem cell markers such as SOX2, OCT4, NANOG, and CRISPR/CAS9-mediated 
Table 1 The application of CRISPR/Cas9 in osteosarcoma research

\begin{tabular}{|c|c|c|c|c|}
\hline $\begin{array}{l}\text { Target } \\
\text { Genes }\end{array}$ & Cell lines & $\begin{array}{l}\text { CRISPR/Cas9 } \\
\text { Applications }\end{array}$ & Effects & References \\
\hline CD11K & $\begin{array}{l}\text { KHOS, } \\
\text { U2OS }\end{array}$ & knock out & $\begin{array}{l}\text { Proliferation } \downarrow \text {, Migration } \downarrow \text {, } \\
\text { Invasion } \downarrow \text {, cell death } \uparrow\end{array}$ & {$[37]$} \\
\hline $\begin{array}{l}\text { GLT25D1, } \\
\text { GLT25D2 }\end{array}$ & Saos2 & knock out & Non-survival cells & [38] \\
\hline CD44 & $\begin{array}{l}\text { MNNG/ } \\
\text { HOS, } \\
143 B\end{array}$ & knock out & Migration $\downarrow$, Invasion $\downarrow$, spheroids formation $\downarrow$ & [39] \\
\hline CD81 & $143 B$ & knock out & $\begin{array}{l}\text { Tumors growth in mice } \downarrow \\
\text { lung metastases } \downarrow\end{array}$ & {$[40]$} \\
\hline FGF5 & $\begin{array}{l}\text { MG63, } \\
\text { U20S }\end{array}$ & knock out & Proliferation $\downarrow$, tumor growth in mice $\downarrow$, MAPK pathway activity $\downarrow$ & [41] \\
\hline $\begin{array}{l}\text { mutant } \\
\text { TP53 }\end{array}$ & $\begin{array}{l}\text { KHOS, } \\
\text { KHOSR2 }\end{array}$ & knock out & 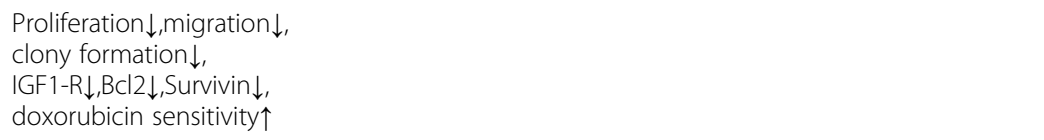 & [42] \\
\hline$P D-L 1$ & $\begin{array}{l}\text { MNNG/ } \\
\text { HOS, } \\
\text { KHOS }\end{array}$ & knock out & Chemoresistance to doxorubicin and paclitaxel $\downarrow$ & [43] \\
\hline CD44 & $\begin{array}{l}\text { KHOSR2, } \\
\text { U-2OSR2 }\end{array}$ & knock out & $\begin{array}{l}\text { Migration } \downarrow \text {, Invasion } \downarrow \text {, } \\
\text { spheroids formation } \downarrow \text {, } \\
\text { doxorubicin sensitivity } \uparrow\end{array}$ & [44] \\
\hline$A B C B 1$ & $\begin{array}{l}\text { KHOSR2, } \\
\text { U-2OSR }\end{array}$ & knock out & doxorubicin sensitivity $\uparrow$ & [45] \\
\hline $\begin{array}{l}\text { CNE9, } \\
\text { CNE10 }\end{array}$ & U2OS & knock out & $\begin{array}{l}\text { Proliferation } \uparrow, \text { apoptosis } \downarrow \text {, } \\
\text { SHOX expression } \downarrow\end{array}$ & {$[46]$} \\
\hline STAG2 & U2OS & knock out & $\begin{array}{l}\text { Proliferation } \downarrow, E M T \uparrow, \text { migration,cisplatin chemoresistance } \uparrow, P D L 1, C D K 4, R B \text { expression } \uparrow, C C N B 1, \\
\text { CCND 1,CDK1 } \downarrow, G 2 / M \text { arrest, } \\
\text { PI3K/AKT Pathwayactivity } \downarrow\end{array}$ & {$[47]$} \\
\hline ESR1 & $143 B$ & knock out & $\begin{array}{l}\text { Proliferation } \uparrow, \text { osteoblast differentiation } \downarrow \text {, tumor growth and metastasis in mouse } \uparrow \text { VIMENTIN, } \\
\text { SLUG,ZEB1,MMP9,SOX2,OCT4,NANOG expression } \uparrow\end{array}$ & {$[48]$} \\
\hline SENP2 & HOS & knock out & Proliferation $\uparrow$,migration $\uparrow$, invasion $\uparrow$, SOX9 expression $\uparrow$ & [49] \\
\hline RECQL5 & MG-63 & knockin & Proliferation $\downarrow$,apoptosis $\uparrow$, cell cycle arrest,bcl-2 $2 \downarrow$,caspase- $3 \uparrow$ & {$[50]$} \\
\hline TP53 & $\begin{array}{l}\text { porcine } \\
\text { zygotes }\end{array}$ & knock out & Genetical porcine model with mandibular osteosarcoma & {$[51]$} \\
\hline RAD52 & U2OS & knock out & $\begin{array}{l}\text { Tumor Growth } \downarrow \text {,lifespan } \uparrow, \\
\text { DNA replication } \downarrow\end{array}$ & [52] \\
\hline $\begin{array}{l}\text { PAWS1, } \\
\text { CD2AP }\end{array}$ & U2OS & $\begin{array}{l}\text { knock out } \\
\text { knockin }\end{array}$ & Migration $\downarrow$,Focal adhesions $\downarrow$,cell adhesion ability $\downarrow$ & [53] \\
\hline NRF2 & U2OS & knock out & No function research & {$[54]$} \\
\hline Cnn3 & U2OS & knock out & $\begin{array}{l}\text { Stress fiber networks organizations and contractility abnormalities. } \\
\text { stress fiber breakage events } \uparrow\end{array}$ & {$[55]$} \\
\hline G3BP & U2OS & knock out & For studying potential proviral roles of G3BP & {$[56]$} \\
\hline $\begin{array}{l}\text { CRY1, } \\
\text { CRY2 }\end{array}$ & U2OS & knock out & For studying circadian rhythms in mouse & {$[57]$} \\
\hline SRGAP2 & $\mathrm{K} 12$ & knock out & Migration $\uparrow$ & {$[58]$} \\
\hline VEGF & K7M2 & knock out & $\begin{array}{l}\text { Proliferation } \downarrow \text {, Migration } \downarrow \text {, } \\
\text { Invasion } \downarrow \text { in vivo and vitro. }\end{array}$ & [59] \\
\hline
\end{tabular}

Notes: $\uparrow:$ Up-regulation: $\downarrow$ :Down-regulation

ESR1 gene knockout, effectively eliminating the abovementioned effects of DAC, and demonstrating that the inhibitory effect of DAC on osteosarcoma depends on the presence of the ESR1 gene [48]. Using the CRISPR/
Cas9 technique, scientists also demonstrated that SENP2, which was expressed at lower levels in primary human osteosarcoma tissue and cell lines, may be a potential target for osteosarcoma treatment. In their study, 


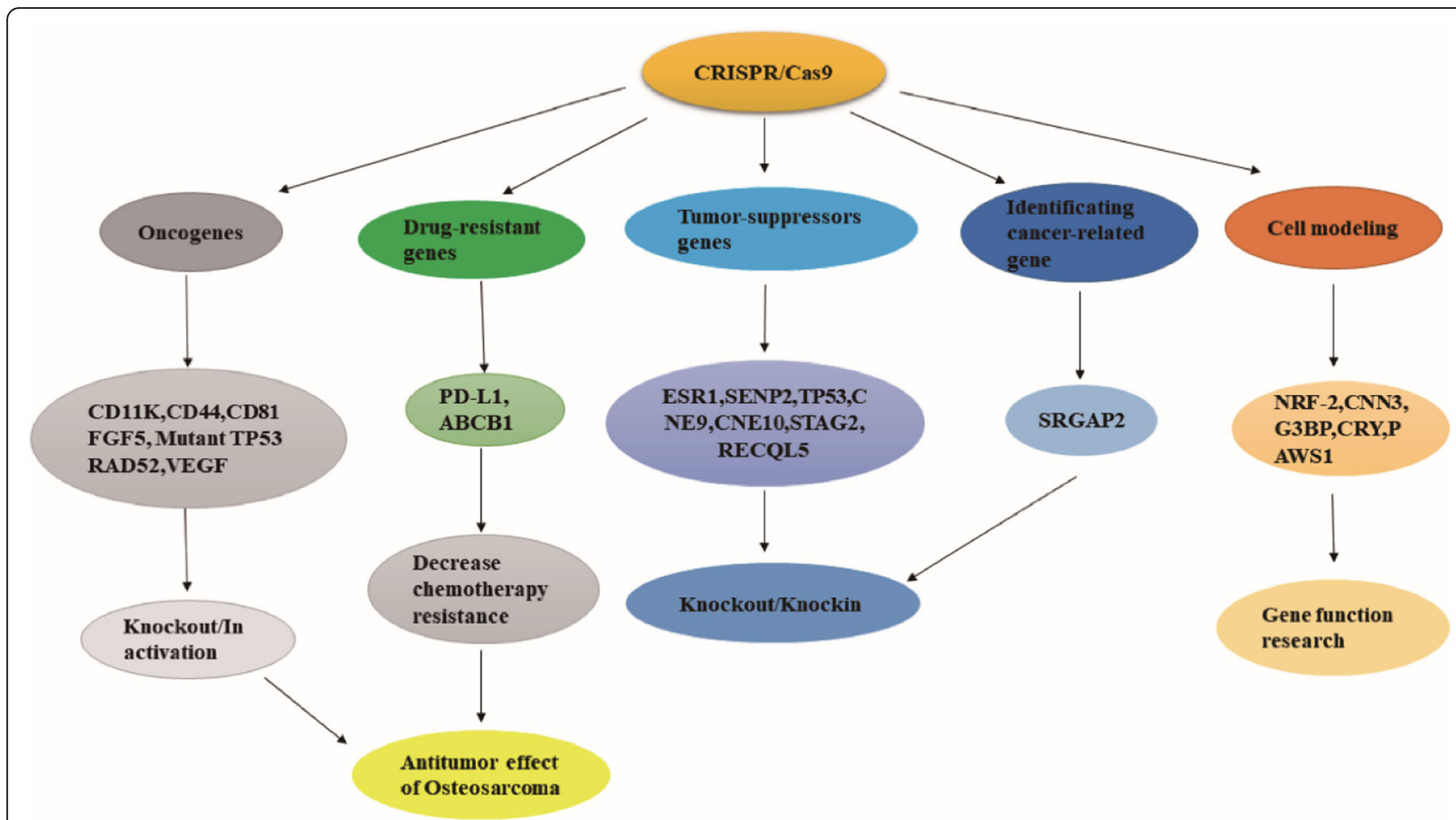

Fig. 2 The application of CRISPR/Cas9 in osteosarcoma research. The applications of CRISPR/Cas9 in the research of osteosarcoma primarily involve in oncogene knockout, drug resistance gene knockout, tumor suppressor gene knockout or knock-in, cancer-related gene identification and cell modelling

engineered SENP2 overexpression significantly inhibited cell proliferation, migration and invasion, which was reversed by CRISPR/Cas9-mediated SENP2-knockout [49]. Similar to gene knockout, CRISPR/Cas9 technology was also applied to construct stable gene overexpression cell lines. RECQL5, a gene that is downregulated in osteosarcoma tissue and cells, was inserted into human AAVS1 safe harbor using the CRISPR/Cas9 system to investigate its function in osteosarcoma progression. A stable RECQ L5 overexpression MG63 cell line was constructed, and significant cell proliferation inhibition, cell cycle arrest and apoptosis promotion were observed, suggesting $R E C Q$ $L 5$ that is a tumor suppressor in osteosarcoma [50].

CRISPR/CAS9 was also used to construct animal or cell models of human osteosarcoma. Tanihara. et al. performed targeted TP53 knockout of pig in vitro zygotes, and half of the live piglets produced after in vivo transplantation developed various tissue tumors, including osteosarcoma. The combination of CRISPR/Cas9 technology and in vitro fertilization technology can effectively reduce the research cost of generating gene-mutant pigs, and generate a pig osteosarcoma model that is similar to the physiological anatomy and genetics of humans, which will certainly provide great help for preclinical osteosarcoma research [51]. In addition, the construction of a RAD52-knockout U2OS cell model through CRISPR/Cas9 technology helped to demonstrate that RAD52 is an important gene for repairing the collapsed DNA replication forks damaged by oncogenes or chemicals in cancer cells, given that Rad52 knockout by CRISPR/Cas9 compromised the restarting of collapsed forks and led to DNA damage [52]. The construction of $P A W S 1$ - and CD2AP-knockout U2OS cell models demonstrated that $P A W S 1$ and $C D 2 A P$ play essential roles in cell actin organization and focal adhesion, thus affecting cell adhesion and migration. Specifically, PAWS1 or $C D 2 A P$ knockout by CRISPR/CAS9 resulted in disorganized and tangled actin mesh, reduced migration ability, and failure to properly form focal adhesions. These findings are beneficial to broaden the research onbiochemical and molecular mechanisms of cytoskeleton structure regulation, and are of great significance for deeply understanding the process of embryonic development, angiogenesis, epithelial-mesenchymal transition and cancer migration [53]. Moreover, some other cell models, such as NRF-2-knockout U2OS for determining the inhibitory mechanism of sulforaphane on mTOR [54]., CNN3-knockout U2OS for investigating its role in stress fibre assembly and contractility [55],G3BP-knockout U2OS for studying potential pro-viral roles of G3BP [56], and CRY1,CRY2-knockout U2OS cell models for studying human circadian clocks [57].

The function of CRISPR/CAS9 technology in screening and identifying cancer-related genes deserves 
attention and further development. For example, Marko. et al. used the cancer gene database to perform forward genetic screening of cancer-driving genes, and screened for the genetic locus SRGAP2 that may be related to the malignant progression of osteosarcoma. Then, they used CRISPR/Cas9 and doxycycline to knock out and overexpress SRGAP2 respectively in murine osteosarcoma cell lines, and found that SRGAP2 knockout increased cell migration, whereas $S R G A P 2$ overexpression reduced cell migration, demonstrating that $S R G A P 2$ may act as a migration inhibitor [58]. Some researchers performed candidate gene analysis, pathway-based gene analysis and genome-wide association studies (GWAS) to screen out pharmacokinetics-associated genes of MAP therapy (i.e., drug metabolism enzymes genes GSTT1,GSTM1, $G S T M 3 * B$, and GSTP1, and transporters genes $A B C B 1$, $A B C B 3$, and RFC1) and pharmacodynamic genes associated with cisplatin treatment(i.e.,DNA damage repair genes REV1,REV3,ERCC1,ERCC2,ERCC5, and XPC) [26]. If CRISPR/CAS9 technology was used for corresponding gene editing, it might have provided more promising molecular targets for osteosarcoma treatment, meanwhile. By identifying more genes or signalling pathways that affect drug efficacy, we can further study whether and how such genes are involved in the genesis and progression of osteosarcoma.

In short, osteosarcoma has a high risk of metastasis and is prone to chemotherapy resistance, and the outcomes of treatment for patients have not improved in decades. The extensive application of CRISPR/CAS9 may solve the above problems in the near future.

\section{Ewing's sarcoma and CRISPR/CAS9}

Ewing's sarcoma is also a common malignancy of the skeletal system, second only to osteosarcoma in incidence, with a rate of 2.93/1 million in the United States for a period of past 30 years. Between 2000 and 2005, an average of 208 new patients were added annually, and greater than one quarter had metastasized at diagnosis [60]. The 10-year survival rate for non-metastatic patients is approximately $66.8 \%$, compared with $28.1 \%$ for metastatic patients [61]. Unlike osteosarcoma, ES has a clear genetic aetiology. Specifically, the EWSR gene of chromosome 22 and the ETS family gene of chromosome 11 are translocated to form a fusion gene, and the ETS family gene includes FL1,ERG,ETV1,ETV4, and $F E V$. In most cases, EWSR is fused with the FL1 gene, accounting for approximately $85 \%$ of cases. The ETS family genes are responsible for encoding transcription factors, enabling fusion genes to have powerful transcriptional activation activities to induce the genesis of ES $[62,63]$. In addition, many other genes were also reported to promote the occurrence and progression of ES, such as the human telomerase reverse transcriptase gene, VEGF, IGF-1, CAV1, EZH2, BMI1, NKX2.2, NROB1, GLI1, RB and $p 53$ [62] .

Current treatments for ES include surgery, radiotherapy and standard chemotherapy consisting of vincristine, doxorubicin, cyclophosphamide, ifosphamide, and etoposide [63]. As the EWSR1-FLI1 fusion protein is located in the nucleus and is difficult to attack directly, traditional chemotherapeutics targeting EWSR1-FLI1 often fail to achieve satisfactory results [64, 65]. Although multimodal treatment strategies have improved patient survival rates to some extent, many problems still exist. These problems are mainly reflected in the low long-term survival rate of survivors, tumor metastasis or recurrence, chemoresistance, and the relatively increased risk of secondary malignancies [62, 66, 67]. According to a national study of ES survivors with greater than 30 years of follow-up in Sweden, the risk of breast cancer is significantly increased by approximately 4.7 times that in the general population, whereas the risk of secondary soft tissue sarcoma is 67 times that in the general population [68]. Cohort studies of 23,603 5-year survivors with childhood tumors in the U. S and Canada show that radiotherapy is an important factor in secondary malignancies [66]. These studies indicate that the long-term outcome of ES patients is not ideal, thus new treatment methods are urgently needed. In recent years, scientists have begun to apply CRISPR/Cas9 technology to ES research, and some progress has been made (summarized in Table 2).

In 2014, CRISPR/Cas9 technology was first used to construct an ES cell model of EWSR1-FLI1 translocation mutations in HEK293 and human adult mesenchymal stem cells (hMSCs) - one of the origin cells of human ES, and EWSR1-FLI1 fusion protein expression was observed. Six genes targeted by the EWSR1-FLI1 gene were also upregulated, demonstrating the potential of CRIS PR/Cas9 technology for cancer modelling of ES [69]. To optimize the efficiency of CRISPR/Cas9, Torres-Ruiz. et al. developed the ssODN-RNP CRISPR/Cas9 coupling method to more efficiently generate $t(11,22)$ translocations in hMSCs and hiPSCs, promoting ES modelling via a combination of stem cell technology and CRISPR/ CAS9 technology [70]. In the same year, Spraggon. et al. developed a novel method that combines CRISPR/Cas9 with HDR to engineer and modulate the expression of chromosomal translocation products, and allowed the expression of the EWSR1-FLI1 fusion gene to be controlled in a timely manner, which effectively solved the problem that the permanent generation of the EWSR1FLI1 fusion gene caused the expression change of its intracellular target gene in a short time and made them difficult to precisely target, This strategy is undoubtedly more conducive to the study of the genetic and pathogenic mechanisms of ES [71]. 
Table 2 The application of CRISPR/Cas9 in Ewing's sarcoma research

\begin{tabular}{|c|c|c|c|c|}
\hline Target Genes & Cell lines & CRISPR/Cas9 Applications & Effects & References \\
\hline EWSR1,FL/1 & $\begin{array}{l}\text { hMSC,hiPSC,HEK293A, } \\
\text { HEK293T }\end{array}$ & $\begin{array}{l}\text { induce chromosomal } \\
\text { translocation }\end{array}$ & EWSR1-FLI1 chromosomal translocation cell model & [69-71] \\
\hline $\begin{array}{l}\text { MDM2,MDM4,TP53,USP7, } \\
\text { PPM1D }\end{array}$ & $\begin{array}{l}\text { TC32,TC138 } \\
\text { A673,EWS502 }\end{array}$ & knock out & $\begin{array}{l}\text { Proliferation } \downarrow \text {, } \\
\text { chemical cytotoxity } \downarrow\end{array}$ & {$[72]$} \\
\hline PHF19 & SK-N-MC & knock out & $\begin{array}{l}\text { Proliferation } \downarrow \text {,colony formation } \downarrow \text {, invasion } \downarrow \text {, JQ1 } \\
\text { sensitivity } \uparrow\end{array}$ & [73] \\
\hline TNC & A673,SKNMC & knock out & $\begin{array}{l}\text { Proliferation } \downarrow \text {,migration } \downarrow \text {, } \\
\text { metastases in mice } \downarrow \text {, } \\
\text { Hippo/YAP pathwayactivity } \downarrow, M A L A T 1, \\
\text { P-SRC,P-MYC expression } \downarrow\end{array}$ & {$[74]$} \\
\hline MSH2 & A673 & knock out & 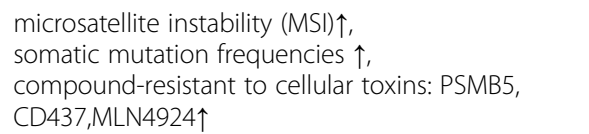 & {$[75]$} \\
\hline
\end{tabular}

Notes: $\uparrow:$ Up-regulation: $\downarrow$ :Down-regulation

In the study of ES gene function, CRISPR/CAS9 technology also demonstrates great value. Stolte. et al. knocked out multiple genes including $M D M 2, M D M 4$, PPM1D and USP7 in mutated TP53 and wild-type TP53 ES cell lines, and they found that cell viability was significantly reduced only in wild-type TP53 cells, suggesting that the presence of wild-type TP53 may be a prerequisite for these oncogenes to play carcinogenic roles. In addition, CRISPR/Cas9 technology was applied for screening cancer-related genes and exploring effective gene-targeted drug combinations in this study. For example, they used CRISPR/Cas9 to edit a number of genes and eventually found that the MDM2/MDM4 double knockout exhibited an increased antitumor effect. Then they combined the MDM2/MDM4 dual inhibitor, ATSP-7041 with doxorubicin, etoposide and vincristine, and achieved a more significant growth inhibition of tumor in xenograft mice than control mice, which provides a theoretical basis for the combination of ATSP-7041 and conventional chemotherapy drugs in clinical use for ES patients [72]. Another study showed that PHF19-knockout significantly reduced cell proliferation, colony formation and invasion capacity, and increased the sensitivity of SK-N-MC ES cells to the BET bromodomain protein inhibitor JQ1 which can reduce proliferation and induce apoptosis of ES cells. This study also revealed the potential of JQ-1 for clinical utility in treating ES [73]. Similarly, TNC-knockout using the CRISPR/Cas9 system in A673 and SKNMC cells significantly inhibits cell proliferation, migration and angiogenesis. After injecting TNC-knockout cells into nude mice, their ability to transfer and colonize in vivo was significantly reduced compared with that of the control [74]. A recent study produced a defective DNA mismatch repair (dMMR) phenotype by knocking out the $M S H 2$ gene in A673 cells, which increased the cell's gene mutation rate, and was used as a forward genetics system to uncover compound targets. Specifically, compound-resistant mutant clones can be obtained after treatment with three cellular toxins, namely, PSMB5, CD437 and MLN4924. This approach which promotes the appearance of compound resistance alleles through CRISPR/Cas9-mediated dMMR can be applied to identify the mechanism of anticancer effects of compounds screened out by phenotypic small molecules, and to model the genetic mechanism of chemoresistance in currently used anticancer therapies [75].

Currently, the use of CRISPR/CAS technology for ES research has only just begun. Although many cell models have been established, effective animal models remain lacking. Therefore, further advancement in animal modelling and cancer-related genetic modification (such as EWS/ETS target genes) of ES by CRISPR/Cas9 technology is needed, and it is expected to provide more options for clinical treatment of ES.

\section{Rhabdomyosarcoma and CRISPR/CAS9}

Among human soft tissue sarcomas, rhabdomyosarcoma has the highest incidence, accounting for approximately $4-5 \%$ of malignancies in children, histologically, it is mainly divided into embryonal sarcomas (ERSMs) and alveolar sarcomas (ARSMs), with the former accounting for approximately $80 \%$ and the latter accounting for approximately 15-20\% [76]. Current treatments for RSM include chemotherapy, surgery, and radiation. Although multidisciplinary treatment strategies cure approximately two-thirds of nonmetastatic RSM patients, the poor prognosis of metastatic and recurrent RSM patients urgently needs to be improved, as their 3-year overall survival rate is only 34 to $56 \%[77,78]$. RSM is mainly derived from skeletal myoblasts. Genetically, ERMS is characterized by allelic deletions on chromosome 11, and the main genetic characteristics of ARSM are chromosomal translocation of 1,13 , and 2, 13, with the production of fusion genes PAX7-FOXO1 or PAX3- 
FOXO1, respectively, which dysregulate various genes that participate in cell transcription and differentiation, thus promoting carcinogenesis. Therefore, ARSM is often more disruptive than ERSM [17, 79, 80]. In addition to fusion genes, many other genes were also considered to be involved in the development of RSM, such as NRAS, KRAS, HRAS, PIK3CA, FBXW7, BCOR, FGFR4 and CTNNB1 [81]. The precise gene modification function of CRISPR/CAS9 technology has enabled its application in RSM research. Current progress achieved by CRISPR/CAS9 technology in the construction of RSM cell models, cancer gene screening and gene function research. is summarized in Table 3.

In 2015, Lagutina. et al. first constructed a human ARSM-like chromosomal translocation $\mathrm{t}(1,3)$ cell model using CRISPR/CAS9 technology in mouse myoblasts [82]. Scientists also used CRISPR/CAS9 to construct DMD-KO $[83,84]$ and Dysf-KO TE671 [85] cells with WT-TE671 human ERSM cells to study the pathophysiology of muscle diseases. For cancer gene screening, scientists applied iExCN analysis tools combined with CRISPR/Cas9 technology to successfully screen and verify dozens of human RMS cancer-related genes such as oncogenes CDCA2, HAS2, SNAI2, WAR, EZH2, SCAR A3, ARL4A, CDK6, ETV1, RAD54B, RIPK2, and ZFHX4, and tumor suppressor genes PTEN, ZRSR2, and TJP2. Many of these genes are related to RSM growth and differentiation [79]. The results of this study provide new ideas for research and gene targeted therapy of RSM.

CRISPR/CAS9 technology was also used to study the function of RSM oncogenes. HDAC3 knockout in $381 \mathrm{~T}$ ERMS cells significantly inhibited cell proliferation in vitro and tumor growth in vivo, and resulted in extensive tumor differentiation in xenograft mice, suggesting the potential value of CRISPR/CAS9 technology in RSM differentiation-induction therapy [86]. To investigate the role of the PAX3-FOXO1 fusion gene in the tumorigenesis and progression of RSM tumors, immortalized human myoblasts with doxycycline-inducible $P A X 3$ FOXO1 and constitutive $M Y C N$ expression constructs were injected into nude mice, and rapid RSM tumors formation was observed, In contrast, myoblasts expressing only PAX3-FOXO1 formed tumors after a longer latency period. Although doxycycline withdrawal resulted in tumor regression, most tumors relapsed without induction of doxycycline. When PAX3-FOXO1 in primary tumor-derived cell lines was knocked out by CRISPR/ CAS9, cell oncogenicity disappeared and these cell lines were differentiated following doxycycline withdrawal. However, recurrent tumor-derived cell lines with $P A X 3$ $F O X O 1$ knockout did not differentiate under these conditions. These findings indicate that PAX3-FOXO1 interacts with $M Y C N$ to promote the occurrence of RSM by

Table 3 The application of CRISPR/Cas9 in Rhabdomyosarcoma research

\begin{tabular}{|c|c|c|c|c|}
\hline Target Genes & Cell lines & $\begin{array}{l}\text { CRISPR/Cas9 } \\
\text { Applications }\end{array}$ & Effects & References \\
\hline Pax3,Foxo1 & $\begin{array}{l}\text { Foxo1-inv+/+ myoblasts (mice)/ } \\
\text { primary myoblasts }\end{array}$ & $\begin{array}{l}\text { induce } \\
\text { chromosomal } \\
\text { translocation }\end{array}$ & $\begin{array}{l}\text { Pax3-Foxo1 chromosomal translocation ARSM model, } \\
\text { no function research }\end{array}$ & [82] \\
\hline$D M D$ & CCL-136 RD & knock out & $\begin{array}{l}\text { Produce DMD deletion - immortalized muscle cell } \\
\text { line }\end{array}$ & {$[83,84]$} \\
\hline DYSF & TE671 & knock out & $\begin{array}{l}\text { Myogenin } \downarrow, T S P-1 \text { expression } \uparrow \text {,membrane Repair } \\
\text { ability } \downarrow \text {, }\end{array}$ & [85] \\
\hline Dozens genes & $\mathrm{JR} 1, \mathrm{RD}$ & knock out & $\begin{array}{l}\text { Validates oncogenes and tumors suppressors defined } \\
\text { by iExCN tool }\end{array}$ & [79] \\
\hline $\begin{array}{l}\text { HDAC1-10 genes (class } \\
\text { I and II HDAC genes) }\end{array}$ & 381 T, RD,SMS-CTR, Rh3,Rh5,Rh30 & knock out & $\begin{array}{l}\text { cell growth } \downarrow \text {, } \\
\text { myogenic differentiation } \uparrow, \\
\text { xenografts tumor proliferation } \downarrow \text {, differentiation } \uparrow,\end{array}$ & [86] \\
\hline PAX3-FOXO1 & $\begin{array}{l}\text { Dbt-MYCN / indP3F parental cells }{ }^{\mathrm{a}} \text {, } \\
\text { recurrent tumour-derived cells. }\end{array}$ & knock out & $\begin{array}{l}\text { Fail to form tumor in Dbt-MYCN/indP3F parental } \\
\text { cells, form tumor in recurrent tumour-derived cells }\end{array}$ & {$[80]$} \\
\hline NRAS,HRAS & 381 T,SMS-CTR ERMS cells & knock out & 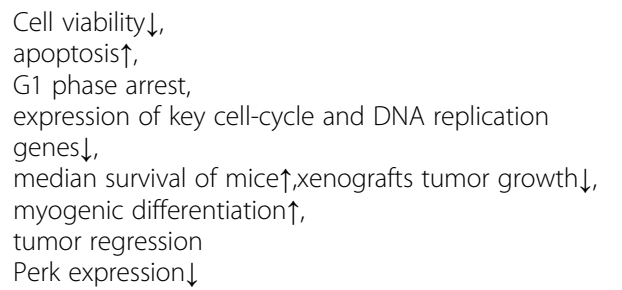 & [87] \\
\hline
\end{tabular}


inhibiting myogenic differentiation and cell death, and recurrent tumours develop in a PAX3-FOXO1-independent manner [80].. In addition, the RAS gene may be another promising target for RSM therapy, as demonstrated by significantly reduced xenograft tumor growth and increased tumor cell death, myogenic differentiation and survival in tumor-bearing mice after the elimination of $R A S$ by CRISPR/CAS9. It is worth noting that in this study, a novel CRISPR/CAS9 MYXV vector delivery system can effectively achieve targeted knockout of the oncogene RAS in tumors of ERMS transplanted mice [87]. This opens up the possibility of providing a new method to solve the problem of in-vivo delivery of CRISPR/CAS9.

In general, CRISPR/CAS9 technology has demonstrated great application potential in RSM research, especially in tumor differentiation-induction therapy, and more research is needed in the future to support its conversion to clinical treatment of RSM.

\section{Application challenges of CRISPR/CAS9}

Given its high genome editing efficiency, CRISPR/CAS9 is not only used to research musculoskeletal malignancies, but also widely used in other human cancers and diseases. The application of CRISPR/CAS9 techniques to screen for pathogenic genes and therapeutic drugs, determine tumor resistance mechanisms, establish tumor models and study the pathogenesis of tumors has undoubtedly brought renewed hope to cancer patients. However it is undeniable that this new technology has just started in human disease research, and there are still many problems and challenges, which are mainly reflected in off-target effects and the efficiency and safety of in vivo delivery systems.

The main reason for the off-target effect is that Cas9sgRNA has sequence mismatch tolerance to target DNA. The same or similar DNA sequences exist in human genome; when Cas9-sgRNA incorrectly recognizes and binds non-target DNA sequences, redundant cutting can be produced, resulting in chromosome rearrangement or off-target mutation [16]. To optimize the precision and specificity of CRISPR/Cas9 genetic modification, scientists have made many efforts in recent years to continuously develop new methods. Generally, there are two methods to reduce the off-target effect: artificially modifying the Cas9 protein or designing new gRNAs [88]. For example, scientists have described a high-fidelity variant of commonly used SpCas9, SpCas9-HF1, that reduces non-specific DNA contact, which maintains similar targeting activity while significantly reducing offtarget genome editing compared to the widely used wild-type SpCas9 [89]. Similarly, scientists developed Sniper-Cas9 using E. coli, which also effectively increased the specificity of the CRISPR/Cas9 system [90].
There are many other studies aimed at reducing offtarget effects, and we believe this challenge of CRISPR/ Cas9 will be effectively solved in future research.

Another challenge for the transfer of CRISPR/Cas9 technology to clinical applications is the in vivo delivery of gene-edited elements. There are currently two main delivery routes: viral vector delivery and physical delivery. The former includes retroviruses, lentiviruses and adenoviruses, with high in vivo delivery efficiency; however, there are concerns about their potential safety and immunogenic risks. The latter includes electroporation and hydrodynamics with relatively high safety but elevated delivery efficiency is needed [16]. It is worth noting that in recent years, scientists have developed a PEG-PEI-cholesterol (PPC) lipopolymer delivery system to successfully achieve targeted delivery of gene editing elements into xenograft tumor in vivo and achieved approximately $50 \%$ gene knockouts in osteosarcoma cells, mainly by delivering the LC09 lipopolymer encapsulating the plasmid encoding VEGFA gRNA and Cas9 to osteosarcoma in situ and lung metastatic sites. The VEGF gene was effectively edited; both the malignant progression of osteosarcoma and lung metastasis were significantly suppressed without toxicity [59]. This success greatly encouraged the application of CRISPR/Cas9 in malignant musculoskeletal tumors. However, the existing research is insufficient to support the clinical transformation of CRISPR/Cas9 technology. There is still a need to further improve the efficiency of targeted delivery of non-viral methods, or to solve the immunogenicity and safety issues of viral vector delivery systems in the future.

\section{Discussion and outlook}

Musculoskeletal malignancies are serious threats to the lives and health of adolescents and children. In addition to osteosarcoma, ES and rhabdomyosarcoma described in this review, it also includes chondrosarcoma and synovial sarcoma, etc. Other risk factors such as high birth weight and adolescent hormones may be related to the occurrence of musculoskeletal sarcoma, but adverse genetic variations must be the most fundamental cause of these diseases. Therefore, it is particularly important to explore the pathogenic genes related to tumorigenesis and development. If scientists can effectively use CRIS PR/Cas9 technology to accurately edit these cancerrelated genes, there is new hope for the treatment of malignant musculoskeletal tumors. Compared with traditional gene editing technology, CRISPR/Cas9 technology is easy to use, more efficient and cheaper. This technology has attracted the attention of scientists and promoted its rapid development in the research of various human diseases, and some breakthroughs have been made in the clinical application of some tumors, 
such as ALL. In addition, some progress has been made in musculoskeletal sarcoma, including oncogene knockout, anticancer drug screening, drug resistance mechanism research, oncogene or tumor suppressor gene screening, and disease modelling. However, there are few reports of the use of CRISPR/Cas9 for musculoskeletal sarcoma gene detection. This may be a research direction that requires further attention. Most importantly, scientists should focus on further development of more efficient and safer CRISPR/Cas9 technology and promote its transformation into clinical use for musculoskeletal malignancy patients as soon as possible. It is clear that CRISPR/Cas9 technology can provide a promising future for malignant musculoskeletal sarcoma patients and potentially revolutionize the clinical treatment of musculoskeletal malignancies.

\section{Conclusion}

Current evidence showed that CRISPR/CAS9 technology was widely used in the field of basic research of musculoskeletal tumors, including screening and knockout of oncogenes or drug-resistant genes, identification of tumor suppressor genes and construction of cell or animal tumor models. And its technical advantages should be utilized to achieve satisfactory clinical treatment outcomes in the future.

\section{Acknowledgments}

Not applicable.

\section{Authors' contributions}

JGR and LW had the idea for the article, LW performed the literature search and data collection, and wrote the first draft of the manuscript, WSB,LBH and ZW were involved in data collection. All authors contributed to the interpretation and revision of the article, and jointly completed the final draft. All authors read and approved the final manuscript. JGR is the corresponding author of this article.

\section{Funding}

This research was supported by the Program of the National Natural Science Foundation of China (grant number 82074233) and Scientific Research Foundation for Advanced Talents, Xiang'an Hospital of Xiamen University (PM201809170009).

\section{Availability of data and materials}

Data sharing is not applicable to this article as no datasets were generated or analysed during the current study.

\section{Ethics approval and consent to participate}

Not applicable.

\section{Consent for publication}

Not applicable.

\section{Competing interests}

The authors declare that they have no competing interests.

\section{Author details}

${ }^{1}$ Department of Orthopaedics, Xiang'an Hospital, School of Medicine, Xiamen University, No. 2000 East Xiang'an Road, Xiang'an District, Xiamen 361102, China. ${ }^{2}$ Department of Obstetrics and Gynecology, Union Hospital, Tongji Medical College, Huazhong University of Science and Technology, Wuhan 430022, China.
Received: 27 August 2020 Accepted: 26 January 2021

Published online: 05 February 2021

\section{References}

1. Ishino $Y$, Shinagawa $H$, Makino K, Amemura M, Nakata A. Nucleotide sequence of the iap gene, responsible for alkaline phosphatase isozyme conversion in Escherichia coli, and identification of the gene product. J Bacteriol. 1987;169(12):5429-33. https://doi.org/10.1128/jb.169.12.5429-5433. 1987.

2. Sorek R, Kunin V, Hugenholtz P. CRISPR--a widespread system that provides acquired resistance against phages in bacteria and archaea. Nat Rev Microbiol. 2008;6(3):181-6. https://doi.org/10.1038/nrmicro1793.

3. Marraffini LA. CRISPR-Cas immunity against phages: its effects on the evolution and survival of bacterial pathogens. PLoS Pathog. 2013;9(12): e1003765. https://doi.org/10.1371/journal.ppat.1003765.

4. Marraffini LA. CRISPR-Cas immunity in prokaryotes. Nature. 2015;526(7571): 55-61. https://doi.org/10.1038/nature15386.

5. Brouns SJJ, Jore MM, Lundgren M, Westra ER, Slijkhuis RJH, Snijders APL, Dickman MJ, Makarova KS, Koonin EV, van der Oost J. Small CRISPR RNAs guide antiviral defense in prokaryotes. Science. 2008;321(5891):960-4. https://doi.org/10.1126/science.1159689.

6. Deveau H, Barrangou R, Garneau JE, Labonté J, Fremaux C, Boyaval P, Romero DA, Horvath P, Moineau S. Phage response to CRISPR-encoded resistance in Streptococcus thermophilus. J Bacteriol. 2008;190(4):1390-400. https://doi.org/10.1128/JB.01412-07.

7. Jinek M, Chylinski K, Fonfara I, Hauer M, Doudna JA, Charpentier E. A programmable dual-RNA-guided DNA endonuclease in adaptive bacterial immunity. Science. 2012;337(6096):816-21. https://doi.org/10.1126/science. 1225829.

8. San Filippo J, Sung P, Klein H. Mechanism of eukaryotic homologous recombination. Annu Rev Biochem. 2008;77:229-57. https://doi.org/10.1146/ annurev.biochem.77.061306.125255.

9. Lieber MR. The mechanism of double-strand DNA break repair by the nonhomologous DNA end-joining pathway. Annu Rev Biochem. 2010;79: 181-211. https://doi.org/10.1146/annurev.biochem.052308.093131.

10. Mali P, Yang L, Esvelt KM, Aach J, Guell M, DiCarlo JE, Norville JE, Church GM. RNA-guided human genome engineering via Cas9. Science. 2013; 339(6121):823-6. https://doi.org/10.1126/science.1232033.

11. Cong L, Ran FA, Cox D, Lin S, Barretto R, Habib N, Hsu PD, Wu X, Jiang W, Marraffini LA, et al. Multiplex genome engineering using CRISPR/Cas systems. Science. 2013;339(6121):819-23. https://doi.org/10.1126/science. 1231143.

12. Ran FA, Hsu PD, Wright J, Agarwala V, Scott DA, Zhang F. Genome engineering using the CRISPR-Cas9 system. Nat Protoc. 2013;8(11):2281-308. https://doi.org/10.1038/nprot.2013.143.

13. Chandrasegaran S, Carroll D. Origins of programmable nucleases for genome engineering. J Mol Biol. 2016;428(5 Pt B):963-89. https://doi.org/10. 1016/j.jmb.2015.10.014

14. Wang $H$, Yang $H$, Shivalila CS, Dawlaty MM, Cheng AW, Zhang F, Jaenisch $R$. One-step generation of mice carrying mutations in multiple genes by CRIS PR/Cas-mediated genome engineering. Cell. 2013;153(4):910-8. https://doi. org/10.1016/j.cell.2013.04.025.

15. Xu L, Wang J, Liu Y, Xie L, Su B, Mou D, Wang L, Liu T, Wang X, Zhang B, et al. CRISPR-edited stem cells in a patient with HIV and acute lymphocytic leukemia. N Engl J Med. 2019;381(13):1240-7. https://doi.org/10.1056/ NEJMoa1817426.

16. Li H, Yang Y, Hong W, Huang M, Wu M, Zhao X. Applications of genome editing technology in the targeted therapy of human diseases: mechanisms, advances and prospects. Signal Transduct Target Ther. 2020;5:1. https://doi. org/10.1038/s41392-019-0089-y.

17. Arndt CAS, Rose PS, Folpe AL, Laack NN. Common musculoskeletal tumors of childhood and adolescence. Mayo Clin Proc. 2012;87(5):475-87. https:// doi.org/10.1016/j.mayocp.2012.01.015

18. Simpson E, Brown HL. Understanding osteosarcomas. JAAPA. 2018;31(8):159. https://doi.org/10.1097/01.JAA.0000541477.24116.8d.

19. Luetke A, Meyers PA, Lewis I, Juergens H. Osteosarcoma treatment - where do we stand? A state of the art review. Cancer Treat Rev. 2014;40(4):523-32. https://doi.org/10.1016/j.ctrv.2013.11.006.

20. Berner K, Johannesen TB, Berner A, Haugland HK, Bjerkehagen B, Bøhler PJ, Bruland ØS. Time-trends on incidence and survival in a nationwide and 
unselected cohort of patients with skeletal osteosarcoma. Acta Oncol. 2015; 54(1):25-33. https://doi.org/10.3109/0284186X.2014.923934.

21. Anninga JK, Gelderblom H, Fiocco M, Kroep JR, Taminiau AH, Hogendoorn PC, Egeler RM. Chemotherapeutic adjuvant treatment for osteosarcoma: where do we stand? Eur J Cancer. 2011;47(16):2431-45. https://doi.org/10. 1016/j.ejca.2011.05.030.

22. Ritter J, Bielack SS. Osteosarcoma. Ann Oncol. 2010;21 Suppl 7:vii320-5. https://doi.org/10.1093/annonc/mdq276.

23. Lipshultz SE, Lipsitz SR, Mone SM, Goorin AM, Sallan SE, Sanders SP, Orav EJ, Gelber RD, Colan SD. Female sex and higher drug dose as risk factors for late cardiotoxic effects of doxorubicin therapy for childhood cancer. N Engl J Med. 1995;332(26):1738-43. https://doi.org/10.1056/ NEJM199506293322602.

24. Aung L, Gorlick RG, Shi W, Thaler H, Shorter NA, Healey JH, Huvos AG, Meyers PA. Second malignant neoplasms in long-term survivors of osteosarcoma: Memorial Sloan-Kettering Cancer Center experience. Cancer. 2002;95(8):1728-34. https://doi.org/10.1002/cncr.10861.

25. Daw NC, Neel MD, Rao BN, Billups CA, Wu J, Jenkins JJ, Quintana J, Luchtman-Jones L, Villarroel M, Santana VM. Frontline treatment of localized osteosarcoma without methotrexate: results of the St. Jude Children's Research Hospital OS99 trial. Cancer. 2011;117(12):2770-8. https://doi.org/10. 1002/cncr.25715

26. Vos HI, Coenen MJH, Guchelaar H-J, Te Loo DMWM. The role of pharmacogenetics in the treatment of osteosarcoma. Drug Discov Today. 2016;21(11):1775-86. https://doi.org/10.1016/j.drudis.2016.06.022.

27. Zhou Y, Liu B, Wang M, Ni J. Endothelin-1 gene polymorphisms and risk of chemoresistant pediatric osteosarcoma. Pediatr Blood Cancer. 2014;61(4): 612-7. https://doi.org/10.1002/pbc.24790.

28. Gorlick R. Current concepts on the molecular biology of osteosarcoma. Cancer Treat Res. 2009;152:467-78. https://doi.org/10.1007/978-1-4419-02849_27.

29. Caronia D, Patiño-Garcia A, Peréz-Martínez A, Pita G, Moreno LT, ZalacainDíez M, Molina B, Colmenero I, Sierrasesúmaga L, Benítez J, et al. Effect of $A B C B 1$ and $A B C C 3$ polymorphisms on osteosarcoma survival after chemotherapy: a pharmacogenetic study. PLoS One. 2011;6(10):e26091. https://doi.org/10.1371/journal.pone.0026091.

30. Liu S, Yi Z, Ling M, Shi J, Qiu Y, Yang S. Predictive potential of ABCB1, ABCC3, and GSTP1 gene polymorphisms on osteosarcoma survival after chemotherapy. Tumour Biol. 2014;35(10):9897-904. https://doi.org/10.1007/ s13277-014-1917-x.

31. Jabeen S, Holmboe L, Alnæs GIG, Andersen AM, Hall KS, Kristensen VN. Impact of genetic variants of RFC1, DHFR and MTHFR in osteosarcoma patients treated with high-dose methotrexate. Pharmacogenomics J. 2015; 15(5):385-90. https://doi.org/10.1038/tpj.2015.11.

32. Salinas-Souza C, Petrilli AS, de Toledo SRC. Glutathione S-transferase polymorphisms in osteosarcoma patients. Pharmacogenet Genomics. 2010; 20(8):507-15. https://doi.org/10.1097/FPC.0b013e32833caa45.

33. Teng J-W, Yang Z-M, Li J, Xu B. Predictive role of glutathione S-transferases (GSTs) on the prognosis of osteosarcoma patients treated with chemotherapy. Pak J Med Sci. 2013;29(5):1182-6. https://doi.org/10.12669/ pims.295.3870

34. Wang MJ, Zhu Y, Guo XJ, Tian ZZ. Genetic variability of genes involved in DNA repair influence treatment outcome in osteosarcoma. Genet Mol Res. 2015;14(3):11652-7. https://doi.org/10.4238/2015.September.28.17.

35. Hao T, Feng W, Zhang J, Sun Y-J, Wang G. Association of four ERCC1 and ERCC2 SNPs with survival of bone tumour patients. Asian Pac J Cancer Prev. 2012;13(8):3821-4. https://doi.org/10.7314/apjcp.2012.13.8.3821.

36. Caronia D, Patiño-García A, Milne RL, Zalacain-Díez M, Pita G, Alonso MR, Moreno LT, Sierrasesumaga-Ariznabarreta L, Benítez J, González-Neira A. Common variations in ERCC2 are associated with response to cisplatin chemotherapy and clinical outcome in osteosarcoma patients. Pharmacogenomics J. 2009;9(5):347-53. https://doi.org/10.1038/tpj.2009.19.

37. Feng Y, Sassi S, Shen JK, Yang X, Gao Y, Osaka E, Zhang J, Yang S, Yang C, Mankin $\mathrm{HJ}$, et al. Targeting CDK11 in osteosarcoma cells using the CRISPRCas9 system. J Orthop Res. 2015;33(2):199-207. https://doi.org/10.1002/jor. 22745.

38. Baumann $\mathrm{S}$, Hennet T. Collagen accumulation in osteosarcoma cells lacking GLT25D1 collagen Galactosyltransferase. J Biol Chem. 2016;291(35):1851424. https://doi.org/10.1074/jbc.M1 16.723379.

39. Liu T, Yan Z, Liu Y, Choy E, Hornicek FJ, Mankin H, Duan Z. CRISPR-Cas9mediated silencing of CD44 in human highly metastatic osteosarcoma cells.
Cell Physiol Biochem. 2018;46(3):1218-30. https://doi.org/10.1159/ 000489072.

40. Mizoshiri N, Shirai T, Terauchi R, Tsuchida S, Mori Y, Hayashi D, Kishida T, Arai Y, Mazda O, Nakanishi T, et al. The tetraspanin CD81 mediates the growth and metastases of human osteosarcoma. Cell Oncol (Dordr). 2019; 42(6):861-71. https://doi.org/10.1007/s13402-019-00472-w.

41. Han D, Wang M, Yu Z, Yin L, Liu C, Wang J, Liu Y, Jiang S, Ren Z, Yin J. FGF5 promotes osteosarcoma cells proliferation via activating MAPK signaling pathway. Cancer Manag Res. 2019;11:6457-66. https://doi.org/10.2147/ CMAR.S200234.

42. Tang F, Min L, Seebacher NA, Li X, Zhou Y, Hornicek FJ, Wei Y, Tu C, Duan Z Targeting mutant TP53 as a potential therapeutic strategy for the treatment of osteosarcoma. J Orthop Res. 2019;37(3):789-98. https://doi.org/10.1002/ jor.24227.

43. Liao Y, Chen L, Feng Y, Shen J, Gao Y, Cote G, Choy E, Harmon D, Mankin H, Hornicek F, et al. Targeting programmed cell death ligand 1 by CRISPR/Cas 9 in osteosarcoma cells. Oncotarget. 2017;8(18):30276-87. https://doi.org/10. 18632/oncotarget.16326.

44. Xiao Z, Wan J, Nur AA, Dou P, Mankin H, Liu T, Ouyang Z. Targeting CD44 by CRISPR-Cas9 in multi-drug resistant osteosarcoma cells. Cell Physiol Biochem. 2018;51(4):1879-93. https://doi.org/10.1159/000495714.

45. Liu T, Li Z, Zhang Q, De Amorim BK, Lozano-Calderon S, Choy E, Hornicek FJ, Duan Z. Targeting ABCB1 (MDR1) in multi-drug resistant osteosarcoma cells using the CRISPR-Cas9 system to reverse drug resistance. Oncotarget. 2016;7(50):83502-13. https://doi.org/10.18632/oncotarget.13148.

46. Xu X-J, Xin S-J, Mao H-Y, Zhang H-J, Chen L-N, Li L, Bai H-L, Huang H-H, Shu M. SHOX CNE9/10 knockout in U2OS osteosarcoma cells and its effects on cell growth and apoptosis. Med Sci Monit. 2020;26:e921233. https://doi.org/ 10.12659/MSM.921233.

47. Nie Z, Gao W, Zhang Y, Hou Y, Liu J, Li Z, Xue W, Ye X, Jin A. STAG2 loss-offunction mutation induces PD-L1 expression in U2OS cells. Ann Transl Med. 2019;7(7):127. https://doi.org/10.21037/atm.2019.02.23.

48. Lillo Osuna MA, Garcia-Lopez J, El Ayachi I, Fatima I, Khalid AB, Kumpati J, Slayden AV, Seagroves TN, Miranda-Carboni GA, Krum SA. Activation of estrogen receptor alpha by Decitabine inhibits osteosarcoma growth and metastasis. Cancer Res. 2019;79(6):1054-68. https://doi.org/10.1158/00085472.CAN-18-1255.

49. Pei H, Chen L, Liao Q-M, Wang K-J, Chen S-G, Liu Z-J, Zhang Z-C. SUMOspecific protease 2 (SENP2) functions as a tumor suppressor in osteosarcoma via SOX9 degradation. Exp Ther Med. 2018;16(6):5359-65. https://doi.org/10.3892/etm.2018.6838.

50. Wu J, Zhi L, Dai X, Cai Q, Ma W. Decreased RECQL5 correlated with disease progression of osteosarcoma. Biochem Biophys Res Commun. 2015;467(4): 617-22. https://doi.org/10.1016/j.bbrc.2015.10.114.

51. Tanihara F, Hirata M, Nguyen NT, Le QA, Hirano T, Takemoto T, Nakai M, Fuchimoto D-1, Otoi T. Generation of a TP53-modified porcine cancer model by CRISPR/Cas9mediated gene modification in porcine zygotes via electroporation. PLoS One. 2018;13(10):e0206360. https://doi.org/10.1371/journal.pone.0206360.

52. Sotiriou SK, Kamileri I, Lugli N, Evangelou K, Da-Ré C, Huber F, Padayachy L, Tardy S, Nicati NL, Barriot S, et al. Mammalian RAD52 functions in breakinduced replication repair of collapsed DNA replication forks. Mol Cell. 2016; 64(6):1127-34. https://doi.org/10.1016/.jmolcel.2016.10.038.

53. Cummins TD, Wu KZL, Bozatzi P, Dingwell KS, Macartney TJ, Wood NT, Varghese J, Gourlay R, Campbell DG, Prescott A, et al. PAWS1 controls cytoskeletal dynamics and cell migration through association with the SH3 adaptor CD2AP. J Cell Sci. 2018;131(1):jcs202390. https://doi.org/10.1242/jcs.202390.

54. Zhang Y, Gilmour A, Ahn YH, de la Vega L, Dinkova-Kostova AT. The isothiocyanate sulforaphane inhibits mTOR in an NRF2-independent manner. Phytomedicine. 2019;153062. https://doi.org/10.1016/j.phymed. 2019.153062 Online ahead of print.

55. Ciuba K, Hawkes W, Tojkander S, Kogan K, Engel U, Iskratsch T, Lappalainen P. Calponin-3 is critical for coordinated contractility of actin stress fibers. Sci Rep. 2018;8(1):17670. https://doi.org/10.1038/s41598-018-35948-6.

56. Götte B, Panas MD, Hellström K, Liu L, Samreen B, Larsson O, Ahola T, McInerney GM. Separate domains of G3BP promote efficient clustering of alphavirus replication complexes and recruitment of the translation initiation machinery. PLoS Pathog. 2019;15(6):e1007842. https://doi.org/10. 1371/journal.ppat.1007842.

57. Börding T, Abdo AN, Maier B, Gabriel C, Kramer A. Generation of human CRY1 and CRY2 knockout cells using duplex CRISPR/Cas9 technology. 2019; 10:577. https://doi.org/10.3389/fphys.2019.00577. 
58. Marko TA, Shamsan GA, Edwards EN, Hazelton PE, Rathe SK, Cornax I, Overn PR, Varshney J, Diessner BJ, Moriarity BS, et al. Slit-Robo GTPase-activating protein 2 as a metastasis suppressor in osteosarcoma. Sci Rep. 2016;6:39059. https://doi.org/10.1038/srep39059.

59. Liang C, Li F, Wang L, Zhang Z-K, Wang C, He B, Li J, Chen Z, Shaikh AB, Liu J, et al. Tumor cell-targeted delivery of CRISPR/Cas9 by aptamerfunctionalized lipopolymer for therapeutic genome editing of VEGFA in osteosarcoma. Biomaterials. 2017;147:68-85. https://doi.org/10.1016/j. biomaterials.2017.09.015

60. Esiashvili N, Goodman M, Marcus RB. Changes in incidence and survival of Ewing sarcoma patients over the past 3 decades: surveillance epidemiology and end results data. J Pediatr Hematol Oncol. 2008;30(6):425-30. https:// doi.org/10.1097/MPH.0b013e31816e22f3.

61. Duchman KR, Gao Y, Miller BJ. Prognostic factors for survival in patients with Ewing's sarcoma using the surveillance, epidemiology, and end results (SEER) program database. Cancer Epidemiol. 2015;39(2):189-95. https://doi. org/10.1016/j.canep.2014.12.012.

62. Toomey EC, Schiffman JD, Lessnick SL. Recent advances in the molecular pathogenesis of Ewing's sarcoma. Oncogene. 2010;29(32):4504-16. https:// doi.org/10.1038/onc.2010.205.

63. Haybaeck J, Roessner A. Malignant round cell tumors : the Ewing sarcoma and beyond. Pathologe. 2020;41(2):116-22. https://doi.org/10.1007/s00292020-00759-y.

64. Balamuth NJ, Womer RB. Ewing's sarcoma. Lancet Oncol. 2010;11(2):184-92. https://doi.org/10.1016/S1470-2045(09)70286-4.

65. Gaspar N, Hawkins DS, Dirksen U, Lewis IJ, Ferrari S, Le Deley M-C, Kovar H, Grimer R, Whelan J, Claude L, et al. Ewing sarcoma: current management and future approaches through collaboration. J Clin Oncol. 2015;33(27): 3036-46. https://doi.org/10.1200/JCO.2014.59.5256.

66. Turcotte LM, Liu Q, Yasui Y, Arnold MA, Hammond S, Howell RM, Smith SA, Weathers RE, Henderson TO, Gibson TM, et al. Temporal trends in treatment and subsequent neoplasm risk among 5-year survivors of childhood Cancer, 1970-2015. JAMA. 2017;317(8):814-24. https://doi.org/10.1001/jama.2017. 0693.

67. Chin M, Yokoyama R, Sumi M, Okita H, Kawai A, Hosono A, Koga Y, Sano H, Watanabe $\mathrm{H}$, Ozaki $\mathrm{T}$, et al. Multimodal treatment including standard chemotherapy with vincristine, doxorubicin, cyclophosphamide, ifosfamide, and etoposide for the Ewing sarcoma family of tumors in Japan: results of the Japan Ewing sarcoma study 04. Pediatr Blood Cancer. 2020;67(5):e28194. https://doi.org/10.1002/pbc.28194.

68. Hesla AC, Discacciati A, Tsagkozis P, Smedby KE. Subsequent primary neoplasms among bone sarcoma survivors; increased risks remain after 30 years of follow-up and in the latest treatment era, a nationwide populationbased study. Br J Cancer. 2020;122(8):1242-9. https://doi.org/10.1038/ s41416-020-0748-3.

69. Torres R, Martin MC, Garcia A, Cigudosa JC, Ramirez JC, Rodriguez-Perales S. Engineering human tumour-associated chromosomal translocations with the RNA-guided CRISPR-Cas9 system. Nat Commun. 2014;5:3964. https://doi. org/10.1038/ncomms4964.

70. Torres-Ruiz R, Martinez-Lage M, Martin MC, Garcia A, Bueno C, Castaño J, Ramirez JC, Menendez P, Cigudosa JC, Rodriguez-Perales S. Efficient recreation of $t(11,22)$ EWSR1-FLI1 $(+)$ in human stem cells using CRISPR/ Cas9. Stem Cell Reports. 2017;8(5):1408-20. https://doi.org/10.1016/j.stemcr. 2017.04.014

71. Spraggon L, Martelotto LG, Hmeljak J, Hitchman TD, Wang J, Wang L, Slotkin EK, Fan P-D, Reis-Filho JS, Ladanyi M. Generation of conditional oncogenic chromosomal translocations using CRISPR-Cas9 genomic editing and homology-directed repair. J Pathol. 2017;242(1):102-12. https://doi.org/ 10.1002/path.4883.

72. Stolte $B$, Iniguez AB, Dharia NA-OX, Robichaud AL, Conway AA-O, Morgan AM, Alexe GA-O, Schauer NJ, Liu XA-OX, Bird GH, et al. Genome-scale CRIS PR-Cas9 screen identifies druggable dependencies in TP53 wild-type Ewing sarcoma. J Exp Med. 2018;215(8):2137-55. https://doi.org/10.1084/jem. 20171066.

73. Gollavilli PN, awar A, Wilder-Romans K, Natesan R, Engelke CG, Dommeti VL, Krishnamurthy PM, Nallasivam A, Apel IJ, Xu T, et al. EWS/ETS-Driven Ewing sarcoma requires BET Bromodomain proteins. Cancer Res. 2018;78(16):476073. https://doi.org/10.1158/0008-5472.CAN-18-0484.

74. He S, Huang Q, Hu J, Li L, Xiao Y, Yu H, Han Z, Wang T, Zhou W, Wei H, et al. EWS-FLI1-mediated tenascin-C expression promotes tumour progression by targeting MALAT1 through integrin a5 31 -mediated YAP activation in Ewing sarcoma. Br J Cancer. 2019;121(11):922-33. https://doi. org/10.1038/s41416-019-0608-1.

75. Povedano JM, Liou J, Wei D, Srivatsav A, Kim J, Xie Y, Nijhawan D, McFadden DG. Engineering forward genetics into cultured Cancer cells for chemical target identification. Cell Chem Biol. 2019;26(9):1315-21.e3. https:// doi.org/10.1016/j.chembiol.2019.06.006.

76. Bisogno G, Jenney M, Bergeron C, Gallego Melcón S, Ferrari A, Oberlin O, Carli M, Stevens M, Kelsey A, De Paoli A, et al. Addition of dose-intensified doxorubicin to standard chemotherapy for rhabdomyosarcoma (EpSSG RMS 2005): a multicentre, open-label, randomised controlled, phase 3 trial. Lancet Oncol. 2018;19(8):1061-71. https://doi.org/10.1016/S1470-2045(18)30337-1.

77. Meza JL, Anderson J, Pappo AS, Meyer WH, Group CsO. Analysis of prognostic factors in patients with nonmetastatic rhabdomyosarcoma treated on intergroup rhabdomyosarcoma studies III and IV: the Children's oncology group. J Clin Oncol. 2006;24(24):3844-51. https:/doi.org/10.1200/JCO.2005.05.3801.

78. Vaarwerk B, Bisogno G, McHugh K, Brisse HJ, Morosi C, Corradini N, Jenney M, Orbach D, Chisholm JC, Ferrari A, et al. Indeterminate pulmonary nodules at diagnosis in Rhabdomyosarcoma: are they clinically significant? A report from the European Paediatric soft tissue sarcoma study group. J Clin Oncol. 2019;37(9):723-30. https://doi.org/10.1200/JCO.18.01535.

79. Xu L, Zheng Y, Liu J, Rakheja D, Singleterry S, Laetsch TW, Shern JF, Khan J, Triche TJ, Hawkins DS, et al. Integrative Bayesian analysis identifies Rhabdomyosarcoma disease genes. Cell Rep. 2018;24(1):238-51. https://doi. org/10.1016/j.celrep.2018.06.006.

80. Pandey PR, Chatterjee B, Olanich ME, Khan J, Miettinen MM, Hewitt SM, Barr FG. PAX3-FOXO1 is essential for tumour initiation and maintenance but not recurrence in a human myoblast model of rhabdomyosarcoma. J Pathol. 2017;241(5):626-37. https://doi.org/10.1002/path.4867.

81. Shern JF, Chen L, Chmielecki J, Wei JS, Patidar R, Rosenberg M, Ambrogio L, Auclair D, Wang J, Song YK, et al. Comprehensive genomic analysis of rhabdomyosarcoma reveals a landscape of alterations affecting a common genetic axis in fusion-positive and fusion-negative tumors. Cancer Discov. 2014;4(2):216-31. https://doi.org/10.1158/2159-8290.CD-13-0639.

82. Lagutina IV, Valentine V, Picchione F, Harwood F, Valentine MB, VillarejoBalcells B, Carvajal JJ, Grosveld GC. Modeling of the human alveolar rhabdomyosarcoma Pax3-Foxo1 chromosome translocation in mouse myoblasts using CRISPR-Cas9 nuclease. PLoS Genet. 2015;11(2):e1004951. https://doi.org/10.1371/journal.pgen.1004951.

83. Maruyama R, Yokota T. Creation of DMD muscle cell model using CRISPRCas9 genome editing to test the efficacy of antisense-mediated exon skipping. Methods Mol Biol. 2018;1828:165-71. https://doi.org/10.1007/9781-4939-8651-4_10.

84. Shimo T, Hosoki K, Nakatsuji Y, Yokota T, Obika S. A novel human muscle cell model of Duchenne muscular dystrophy created by CRISPR/Cas9 and evaluation of antisense-mediated exon skipping. J Hum Genet. 2018;63(3): 365-75. https://doi.org/10.1038/s10038-017-0400-0.

85. De Luna N, Suarez-Calvet X, Garicano M, Fernandez-Simon E, Rojas-García R, Diaz-Manera J, Querol L, Illa I, Gallardo E. Effect of MAPK inhibition on the differentiation of a Rhabdomyosarcoma cell line combined with CRISPR/Cas9 technology: an in vitro model of human muscle diseases. J Neuropathol Exp Neurol. 2018;77(10):964-72. https://doi.org/10.1093/jnen/nly078.

86. Phelps MP, Bailey JN, Vleeshouwer-Neumann T, Chen EY. CRISPR screen identifies the NCOR/HDAC3 complex as a major suppressor of differentiation in rhabdomyosarcoma. Proc Natl Acad Sci U S A. 2016; 113(52):15090-5. https://doi.org/10.1073/pnas.1610270114.

87. Phelps MP, Yang H, Patel S, Rahman MM, McFadden G, Chen E. Oncolytic virus-mediated RAS targeting in Rhabdomyosarcoma. Mol Ther Oncolytics. 2018;11:52-61. https://doi.org/10.1016/j.omto.2018.09.001.

88. Moon SB, Kim DY, Ko J-H, Kim J-S, Kim Y-S. Improving CRISPR genome editing by engineering guide RNAs. Trends Biotechnol. 2019;37(8):870-81. https://doi.org/10.1016/j.tibtech.2019.01.009.

89. Kleinstiver BP, Pattanayak V, Prew MS, Tsai SQ, Nguyen NT, Zheng Z, Joung JK. Highfidelity CRISPR-Cas9 nucleases with no detectable genome-wide off-target effects. Nature. 2016;529(7587):490-5. https:/doi.org/10.1038/nature16526.

90. Lee JK, Jeong E, Lee J, Jung M, Shin E, Kim Y-H, Lee K, Jung I, Kim D, Kim S, et al. Directed evolution of CRISPR-Cas9 to increase its specificity. Nat Commun. 2018;9(1):3048. https://doi.org/10.1038/s41467-018-05477-x.

\section{Publisher's Note}

Springer Nature remains neutral with regard to jurisdictional claims in published maps and institutional affiliations. 